\title{
Esterification of Glucose by Coconut Oil Fatty Acids Using Immobilized CandidarugosaLipaseE.C.3.1.1.3. inCa-alginate Matrix
}

\author{
Sri Handayani, SyarifahHasna, SiswatiSetiasih, SumiHudiyono* \\ Departement of Chemistry, Faculty of Mathematics and Science, University of Indonesia \\ Kampus UI Depok 16424, Indonesia
}

\begin{abstract}
In this study, the synthesis of fatty acid - carbohydrate esters used glucose $(G)$ and coconut oil fatty acid (FA). The esterification reaction was carried out enzymatically using Candida rugosalipase in organic solvent (n-hexane). Lipase was immobilized on Ca-alginate gel beads withthe optimum condition for immobilization was1 \% of Na-alginate, resulting 61.66\% immobilization yield. The optimum conditions for esterification using immobilized lipase in Ca-alginate were at $35^{\circ} \mathrm{C}$, the molar ratio 1:60 (G/FA), 16 hours incubation time and $0 \mathrm{~g}$ molecular sieve. Characterization of synthesized product with FT-IR showed that product exhibit the absorbtion of ester functional group at $1737 \mathrm{~cm}^{-1}$, but with thegreater OH groupabsorption peakat $3344.57 \mathrm{~cm}^{-1}$ indicatedthat the degree ofesterificationwas still low. The synthesized product was then examined by simple emulsion test and was proved to be an emulsifier. Based on theemulsion test, it was known that theproducts ofthe reactionwereglucoseestersthat have propertiesampiphilicas anemulsifiersystem ofoil-inwater emulsion $(\mathrm{o} / \mathrm{w})$.
\end{abstract}

Keywords: glucose ester, Candida rugosalipase, lipase immobilization, Ca-alginate, coconut oil fatty acid

\section{Introduction}

Along with the increasing awareness of health and good environment, the demand for environmentally friendly emulsifiers and easily degradable are increasing. One of emulsifier that meets these criteria is fatty acid esters of carbohydrates, because the ester is derived from material that is easily degraded and renewed [1]. Carbohydrate fatty acid esters can be synthesized from glucose and fatty acid chain usually 10C or more $[2,3]$.As an abundant commodity in Indonesia, coconut oil has a lot of potential. One is as a source of fatty acid. The highest fatty acid content of coconut oil is lauric acid (C12:0) that can be used for the synthesis of fatty acid esters of carbohydrates.

Synthesis of glucose ester can be done either chemically or enzymatically. Enzymatic reaction is generally preferred because it does not require extreme reaction conditions. Nevertheless, the enzymatic reactions cost very high because the enzymes used in the reaction cannot be retrieved and reused in the next cycle of reaction.One of the solutions for this problem is by immobilizing the enzyme on a non-soluble matrix. Enzyme modificationby immobilization is widely used in industry. Immobilization of enzymes on an inert and insoluble matrix were known to have several advantages, among which tends to stabilize the structure of the enzymes thereby increasing the resistance of enzymes to the conditions of $\mathrm{pH}$, temperature, and organic solvents [4]. Immobilization studies of lipase known also to enhance the catalytic activity for the esterification reaction and are able to maintain the catalytic activity until a few days after deposit [5,6,7].

Alginate, anaturalpolysaccharide, is onematerialthat can beusedas animmobilizationmatrix. Alginatehas theability toform agelwhenreactedwithdivalent cations. Immobilizationmethodusingalginatecan bedoneat room temperature.In this study, theCandidarugosalipase was immobilizedinCa-alginate gelmatrix.Studiedincludethe influence ofalginateconcentrationon the results ofimmobilizationandinfluence of temperature, the ratio ofglucosetofattyacids, incubation time, and theweight ofmolecular sieveenzymaticesterificationreactions.

\subsection{Materials}

\section{Materials And Methodes}

The materials used were Candida rugosa lipase EC. 3.1.1.3. obtained from Sigma Aldrich (Singapore), Na-alginate obtained from Sigma Aldrich (Singapore), trisHCl, glucose monohydrate, and hexane obtained from Merck (Indonesia). Coconut oil was purchased from a super market in Jakarta. All chemicals have pa quality and used directly without further purification. 


\subsection{Methodes}

2.2.1 Fatty acid composition of coconut oil.

Determination offattyacid compositionof coconut oilis done bystandard methodsGCanalysisoffattyacid methyl esterform(FAME)

\subsubsection{Hydrolysisof Coconut Oil.}

A total of 20 gof coconut oilput in athree-neckroundflaskand then wasadded with $100 \mathrm{mLof} 1.0$ MKOHin 95\% alcohol. The mixturewas thenheatedbyrefluxsystemfor $1 \mathrm{hr}$ at $62+2{ }^{\circ} \mathrm{C}$ andstirredby amagnetic stirrer. Once heated, the mixturewas added by $50 \mathrm{~mL}$ ofdistilled waterand $35 \mathrm{~mL}$ ofHCl3.0N.The organic phasewas extractedwith $50 \mathrm{~mL}$ ofn-hexane twiceto removefattyacids from water phase. Furtherinto theorganic phasewas added $1.0 \mathrm{gNa}_{2} \mathrm{SO}_{4}$ anhydrous anddodecantationto separate $\mathrm{Na}_{2} \mathrm{SO}_{4}$. Furthermore, the solventn-hexane was evaporated using rotator evaporator until there sulting filtrate concentrated. The filtrate obtained was hydrolyzed fatty acids to be used in the sub sequent experiments.

\subsubsection{Immobilization ofLipaseonCa-alginate matrix.}

The immobilized method used was a direct entrapment [8]. A total of $2.0 \mathrm{~mL}$ of lipase solution was mixed with $8 \mathrm{~mL}$ of Na-alginate to produce a ratio of enzyme/alginate $(w / w)$ of 0.125 . The mixture was stirred with magnetic stirrer to mix evenly. The solution was added dropwise using a syringe into $10.0 \mathrm{~mL}$ of $50.0 \mathrm{mM}$ $\mathrm{CaCl}_{2}$. Ca-alginate beads were formed for 20 minutes and then separated from the solution by vacuum filtration. The beadswere washed on the filter twice with 50.0mMTris buffer solution $\mathrm{HCl} \mathrm{pH} \mathrm{7.2.} \mathrm{Collected} \mathrm{filtrate} \mathrm{was}$ analyzed to determine loading value ofimmobilized enzyme. This value was used to determine the number of $\mathrm{mg}$ of protein in Ca-alginate bead. Loading value was calculated by equation (1).

$$
\text { Loading value }(\%)=\frac{C_{i} V_{i}-C_{f} V_{f}}{C_{i} V_{i}} \times 100
$$

$C_{i}$ istheinitialproteinconcentrationand $C_{f}$ istotalproteinconcentrationinthefiltratethatwasdeterminedbyLowrymetho d[9], while $V_{i}$ is theinitial volume ofthe proteinand $V_{f i}$ isthe totalvolume offiltrate.

Variations inNa-alginate concentrationsused were $1.0 \%, 1.5 \%$, and $2.0 \%(\mathrm{w} / \mathrm{v})$. The optimum conditionswere determinedby the largest efficiency ofmmobilization.Immobilizationefficiency valuedescribed how muchimmobilized enzymein the matrixstillhas thecatalytic activityanda benchmarkof successimmobilizationprocess. Immobilizationefficiency valuswere calculated usingequation(2).

$$
\text { Immobilization efficiency }(\%)=\frac{a_{\text {immo }}}{a_{\text {free }}} \times 100
$$

$a_{f r e e}$ is the specificactivityoffreelipase, and $a_{i m m o}$ is thespecific activityof theimmobilized lipase. The specific activityis definedas theimmobilelipaseactivitypermgprotein. Theactivityoffreelipaseandlipaseimmobile isdetermined bytitrimetricmethod. The number ofmg ofprotein inimmobilelipasewas determined from theloadingvalue.

\subsubsection{Optimization ofFatty Acid-Glucose Esterification.}

Esterification reaction was carried out in $100-\mathrm{mL}$ container. A total of $0.1 \mathrm{mmol}$ of glucose was reacted with fatty acids of coconut oil hydrolyzate $(1-9 \mathrm{mmol})$, with $\mathrm{n}$-hexane as a non-polar solvent as much as $1: 1 \mathrm{v} / \mathrm{v}$ substrate. Then the solution was added by $1.0 \mathrm{~g}$ lipase beads - Ca-alginate and molecular sieve $(0-0.7 \mathrm{~g})$ which was activated by heating temperature of $400{ }^{\circ} \mathrm{C}$ for 3 hours. The mixture was then shaken in a horizontal incubator shaker at $200 \mathrm{rpm}$ at the desired temperature and time [10]. The reactions were terminated by heating at $80{ }^{\circ} \mathrm{C}$

Reaction carried triplo by variations in temperature, the ratio between the molar ratio of glucose and fatty acids, incubation time, and the weight of molecular sieve used. The variations in incubation time taken were $4,8,16$, and 32 hours. The variations of the reaction temperature used were $30,35,40$, and 45 ${ }^{\circ} \mathrm{C}$.Variations in molar ratio of glucose and fatty acids used were 1:10, 1:30, 1:60, and 1:90. Variations of molecular sieve used were $0.0 ; 0.1,0.4$, and $0.7 \mathrm{~g}$.

\subsubsection{Analysis ofEsterification Products.}

Esterificationreaction productswere analyzed bytitration methodfordetermining thepercentconversion offattyacidsandbe repeatedthree times.Titrationperformed usingNaOH solution. Percentconversion offattyacidswas determinedbyequation(3),[10].

$$
\% \text { Conversion }=\frac{\left(\mathrm{V}_{\text {blank }}-\mathrm{V}_{\text {sample }}\right) \times[\mathrm{NaOH}]}{\text { mol fatty acid }} \times 100
$$

\subsubsection{Separationand Identification of EsterificationProducts.}

Separation of esterification products were done by centrifugation. This process was carried out with a speed of $3400 \mathrm{rpm}$ for 15 minutes. Identification of products made using FT-IR instrumentation and emulsifier 

test. Emulsifier test made by mixing approximately $1.0 \mathrm{~mL}$ of water with 10 drops of oil, then the addition of glucose ester synthesis results while continuing to be shaken and see the changes. When the emulsion was formed, it observes on the stability of the emulsion for 24 hours.For the determination of the type of emulsion formed was done by dripping a drop of emulsion on glass preparations. After that, the preparatewasaddedby eosin. Testing was done by observation using a microscope to determine whether the emulsion that forms an emulsion of oil in water $(\mathrm{o} / \mathrm{w})$ or water-in-oil (w/o).

\section{Result And Discussion}

\subsection{Coconut OilFatty Acids Composition.}

The analysis results offatty acids composition incoconutoil gave the maximum composition of Lauric acid $(54.10 \%)$. The averageMr of fattyacidis207.89 that were used for mole calculation of fatty acid needed in experiment. Composition and its contribution to average Mr fatty acid as can be seen at Table 1 .

Table 1.The fatty acid composition of coconut oil used and its contribution to average Mr.

\begin{tabular}{|l|c|c|c|}
\hline \multicolumn{1}{|c|}{ Fatty Acid } & Mr & Percentage(\%) & Contribution to Mr \\
\hline Caprilic(Oc, C8: 0) & 144.0 & 7.20 & 10.37 \\
\hline Capric(D, C10: 0) & 172.0 & 8.02 & 13.79 \\
\hline Lauric(L, C12: 0) & 200.0 & 54.10 & 108.20 \\
\hline Miristic(M, C14: 0) & 228.0 & 17.40 & 39.67 \\
\hline Palmitic(P, 10:0) & 256.0 & 6.64 & 17.00 \\
\hline Stearic(S, C18: 0) & 284.0 & 1.86 & 5.28 \\
\hline Oleic(O, C18: 1) & 282.0 & 3.99 & 11.25 \\
\hline Linoleic(L, C18: 2) & 280.0 & 0.81 & 2.27 \\
\hline Linolenic(Ln, C18: 3) & 278.0 & 0.02 & 0.06 \\
\hline \multicolumn{3}{|l|}{} & \\
\hline
\end{tabular}

\subsection{Triglyceridehydrolysis ofcoconut oil.}

The hydrolysis of triglycerides of coconut oil performed under alkaline condition. Hydrolysis carried out using 95\% $\mathrm{KOH}$ in alcohol gives better results and more soluble fatty acid salt in water than the results with $\mathrm{NaOH}$ [11]. The addition of water into the reaction mixture serves to separate saponification to unsaponification products. The product of reaction mixture, which was a potassium salt-fatty acid,was then converted into its acid form by the addition of excess hydrochloric acid and separated from the mixture by extractingwith n-hexane. The results of the fatty acid are then used as substrates in subsequent experiments. Percent yield of hydrolysis was $92.80 \%$.

\subsection{Optimization ofCandidarugosaLipaseImmobilizedinCa-alginate matrix.}

Immobilizationmethod oflipaseinCa-alginate beadmatrixis anentrappingmethod, namelyentrapmentof enzyme moleculesin thecavities ofalginate matrix. Ca-alginate beadis formed whensodiumalginatesolutionis drippedinto a solution of $\mathrm{CaCl}_{2}$. This isdue to thecrosslinkingbetween thedivalent cations $\mathrm{Ca}^{2+}$ withcarboxylateanions(- $\mathrm{COO}^{-}$) of themonomerguluronat $(\mathrm{G})$ in thealginatemolecules, forming athreedimensional networkin the form ofa gel[12]. Immobilization oflipasein a matrix ofCa-alginate occurs whena solution ofalginateis mixedwith a solution ofthe enzymelipaseto formgelbeadsand becausecross linkingbetweenalginatewithcations $\mathrm{Ca}^{2+}$ led tothe formation ofa gel.The two factorsthat affectthe processofimmobilizationare thesolution concentrationalginateused and theconcentration of the solutionCaCl $\mathrm{as} \mathrm{a}_{2}$ source of divalentcations [8]. Based on someresearch on theimmobilizationbyCa-alginate matrix, the concentration of $\mathrm{CaCl}_{2}$ did nothave a significant influenceonthe amount of enzymetrapped(loading value)as well asthe efficiency ofimmobilizationcomparedwith theconcentration ofalginate. On the basis ofthis,in this studyvariedonlythe alginateconcentrationsare $1,1.5$ and $2 \%$. Theloadingvalueandtheimmobilizationefficiency byalginateconcentrationscan be seenin Fig.1.

Based on the results obtained, the higher the concentration of alginate used, the higher the loading value, but the value of the immobilization efficiency decreased. This is because the anion alginate crosslinked with $\mathrm{Ca}^{2+}$ ions, the increase in the concentration of alginate cross allegedly makes connective tissue more and more. The amount of connective tissue makes the rate of diffusion to cross into or out through the smaller matrix $[8,13,14]$. The Candida rugosa lipase $(56 \mathrm{kDa})$ can not diffuse out the matrix, so that the value loading is high. However, the rate of substrate diffusion into the matrix are also small, it makes difficult to reach the enzyme that makes in a small value of immobilization efficiency. Based on these results, it was found that 
Esterification of Glucose by Coconut Oil Fatty AcidsUsingImmobilized CandidarugosaLipase alginate concentration for the immobilization was $1.0 \%(\mathrm{w} / \mathrm{v})$ generate loading value and immobilization efficiency of $40.50 \%$ and $61.66 \%$.

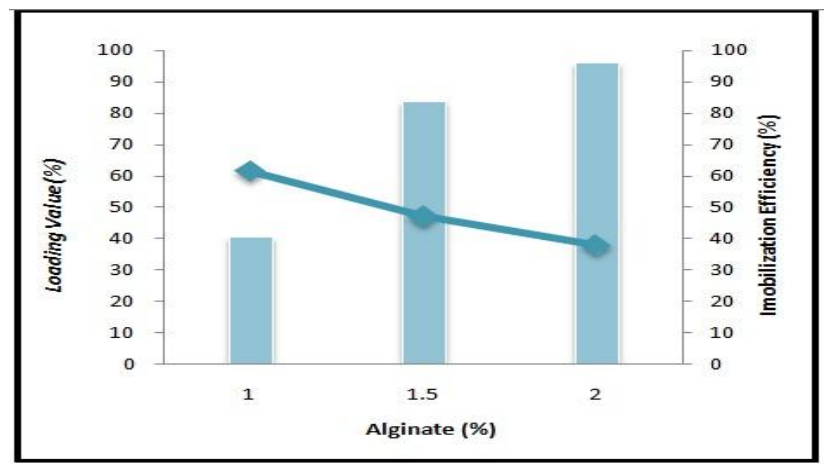

Figure 1.The effect ofalginateconcentrationsto theloadingvalue (\%) and theimmobilizationefficiency $(\%)$. The loadingvalue (bar) and theimmobilizationefficiency $(\bullet)$.

\subsection{OptimizationofLipaseimmobileCa-alginate inEsterificationReaction.}

The purpose of immobilizedlipase in Ca-alginate on the esterification reaction is the enzyme can be used repeatedly. This is supported by a previous study using Ca-alginate immobile lipase as biocatalyst esterification reaction [15].

To find out the esterification reaction, itanalyseby titrimetric indirectly by measuring the reduction of fatty acids in the reaction mixture [10].

In theenzymaticesterificationreaction, there are some factors thatinfluence the course ofthe reaction such as:solvents are used, the ratioof fatty acidsubstratestoglucose, temperature and pHbuffer used. In this study, $\mathrm{n}$-hexane used as solventhavinga $\log$ Pvalue of 3.5. SolventswithlogPvaluesranging from 2 to 4 are selectedonthe esterification reaction.Whenusedsolventswithhighlog Pvalue, mayresult in differencesbetween thesolventpolaritiestoglucoseso the contactbetween theglucosetofattyacidis getting smaller. In thestudy ofesterificationbylipaseis alsoknown thatthe use ofn-hexane as asolventgavethe best results[15,16,17]. The use ofn-hexane solventrestricted $1: 1 \mathrm{v} / \mathrm{v}$ substratebecause ifthe ratio istoo largecancause dehydrationsolipaseactivitydecreased.Reaction wasperformed atpH 7.2inTris-HClbufferpH, it is in line to theresults of previous studiesthatoptimally betweenpH 6,5 - 7,5[8].

Incubation temperature variations performed to determine the optimal temperature of the esterification reaction. The largest percentage conversion of the fatty acid was obtined at a temperature of $35^{\circ} \mathrm{C}$, Fig.2a, according to the previous study shown that thelipaseoptimal temperatureis between $30-35^{\circ} \mathrm{C}[18]$. Previous studies using the free enzyme get the optimum temperature at $30{ }^{\circ} \mathrm{C}$. This is because the use of lipase immobilized on Ca-alginate gel matrix required a greater kinetic energy. Substrate ratio of glucose to fatty acids used was at least twice the number of carboxylic groups on the number of hydroxyl groups ofthe carbohydrate [19.20]. Used excess reactant ratios as expected the reaction equilibrium will shift towards the formation of the product. In addition, the magnitude of the ratio of fatty acids can also be non-polar system so as to minimize the water content in the system.

In this research, percent conversion increase with increasing ratio up to1:60, but above that ratio, the percent conversion decreased; Figure 1b. High substrate concentration will increase the rate of reaction until it reaches theoptimum limit. However, too high concentration of fatty acids can lead to free carboxylic acid groups or ionized high. This causes the water layer (essentially water) around the enzyme is acidic, so the lipase protein tertiary structure is unstable and tends to change on under normal conditions [15].

The optimal incubation time was 16 hours, Figure 2c. Decrease in percent conversion after 16 hours due to the amount of water formed causing mass transfer resistance immobile substrate of the enzyme[15]. Another cause is hydrolysis of ester product, so that the percent conversion was reduced.

Esterification reaction is an equilibrium reaction and one of its products is water. To that end, there should be decreased the water from the reaction mixture, one way is to use molecular sieve. In this study, the addition of molecular sieve turns causes a decrease in the value of percent conversion, Figure $2 \mathrm{~d}$. This was related to the physical form immobile lipase used. Ca-alginate gel matrix used for immobilization of lipase also has water content as a framework constituent gel. The greater of molecular sieve used would interfere with lipase immobile Ca-alginate. This is due to the power of molecular sieve dehydration is very large, resulting in water that make the water of the alginate gel is absorbed out of the alginate molecules. Molecular alginate matrix dehydrated causes to be damaged and result in decreased immobile lipase activity. 


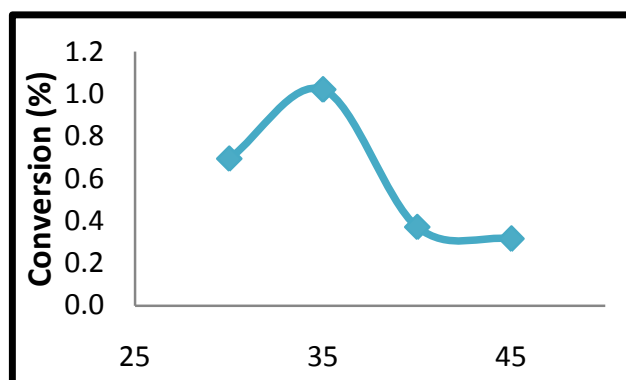

(a)

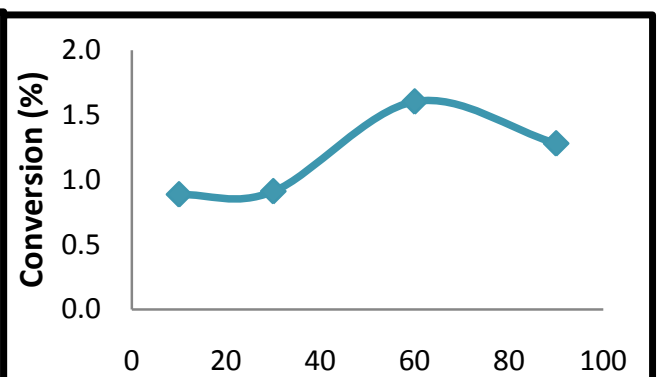

(b)

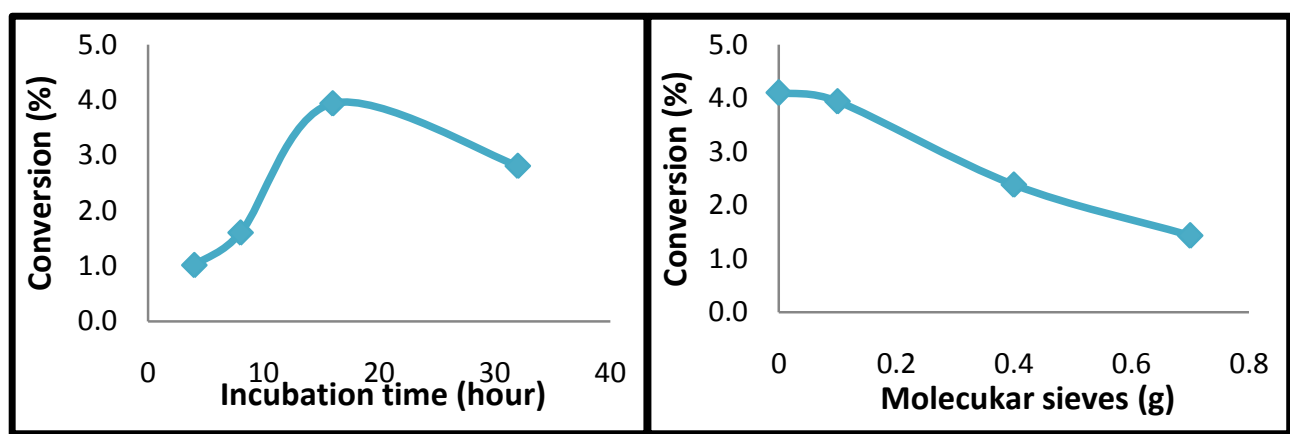

(c)

(d)

Figure 2.The effect oftemperature(a), the ratio ofthe substrate G:FA(b), incubation time(c) andmolecular sieve added(d) to thepercentconversion ofglucose-fatty acid esters.

\subsection{Identification of GlucoseEsters Products}

Identification esterification products byFT-IR aim to look atthequalitativefunctional groupspresent inthe compound.FT-IRspectra showed the appearance ofabsorption bandsforester groupsinthe region1750 $1735 \mathrm{~cm}^{-1}$. The other isthe absorption peakinthe region $3500-3200 \mathrm{~cm}^{-1}$ which is theabsorption bandof alcohol$\mathrm{OH}$ group. It is mean thatstillindicatesthe presence ofnon-esterifiedhydroxyl groups, whichsuggests thatglucoseestersynthesis, has alowdegree of substitution. Fattyacid estersof carbohydratesaredifficult be synthesizedenzymaticallytoproduce products witha highdegree of substitution[1]. Steric hindranceofcarbohydrateused (glucose) is high enough; it can be seen fromthe number ofprimary-OH group thatis onlyonepiece, so that theesterificationreactiontoproduce products witha highdegree of substitutionbecomesdifficult.

The producthasa lowdegree of substitutionand canbe servedas an emulsifier. Ester groupis non-polar andunsubstitutedhydroxyl groupisthe groupof polar andmoresolublein water. To provethis, doa simpletestof the productemulsionis formed, Figure 3a,b.and theobservation of theemulsionsystemformed, Figure $3 \mathrm{c}$. Based on observationswith themicroscope, it was known that the emulsion systemformedwasan emulsionof oilin water(o/w).

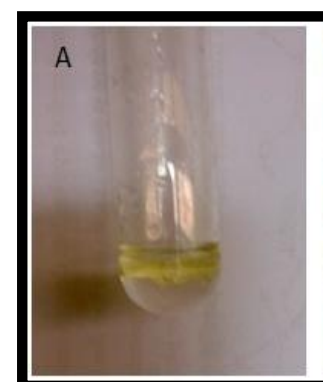

(a)

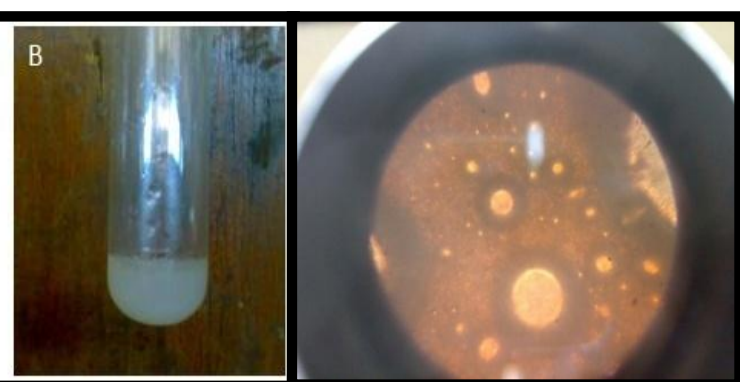

(c)

Figure 3.Simpleemulsiontest resultsprior tothe addition ofthe reaction product(a) afteraddition ofthe reaction product(b) and theobservation ofemulsionsformedwith a microscopeis knownthat the emulsionformed isan emulsionof oilin water(o/w). 


\section{Conclusion}

Lipase was successfully immobilized in Ca-alginate gel matrix.The immobilization of Candida rugosa lipase on Ca-alginate was found to be optimized when using $1 \%$ alginate solution, resulting $61,66 \%$ immobilization yield. The optimum conditions for esterification reaction were at $35^{\circ} \mathrm{C}$, glucose fatty acid ratio 1:60 mmol, 16 hours incubation time, and without using molecular sieve.

Synthesis of glucose esters of fatty acids can be made using the results of hydrolysis of coconut oil catalyzed byimmobilized Candida rugosa lipase on Ca-alginate. Identify products with FT-IR showed absorption peaks $\mathrm{C}=\mathrm{O}$ ester group at wave numbers $1737.86 \mathrm{~cm}^{-1}$, but with the great $\mathrm{OH}$ group absorption peak at wavenumber $3344.57 \mathrm{~cm}^{-1}$ indicates that the degree of esterifikasinyais still low. Based on the test emulsion, it is known that the reaction products glucose esters are compounds that have properties amphiphilic as an emulsifier and established as a system of oil-in-water emulsion $(\mathrm{o} / \mathrm{w})$.

\section{Acknowledgment}

Thank youto theUniversityofIndonesiaforfinancial supportof thisresearch.

\section{Refferences}

[1]. Youchun, Y. (2001). Enzymatic Production of Sugar Fatty Acid Esters. Institut für Technische Biochemie der Universität Stuttgart.

[2]. Adamopoulos, Lambrini. (2006). Understanding the formation of sugar fatty acid esters.Faculty of North Carolina State University.

[3]. Yoo, I. S., Park, S. J., \& Yoon, H. H. (2007). Enzymatic Synthesis of Sugar Fatty Acid Esters. J. Ind. Eng. Chem. 13 , 1-6.

[4]. Matsumoto, M., \& Ohashi, K. (2003). Effect of Immobilization on Thermostability of Lipase from Candida rugosa. Biochemical Engineering Journal 14, 75-77.

[5]. da Silva, V. C., Cintesini, F. J., \& Carvalho, P. (2008). Characterization and Catalytic Activity of Free and Immobilized Lipase from Aspergillus niger: A Comparative Study. J. Braz. Chem. Soc 19, 1468-1474.

[6]. Balcao, V. M., Pavia, A. L., \& Malcata, F. X. (1996). Bioreactors with Immobilized Lipases: State of the Art. Enzyme and Microbial Technology $18,392-416$.

[7]. Öztürk, Banu. (2001). Immobilization of Lipase from Candidarugosa onHydrophobic and Hydrophilic Supports. Đzmir Institute of Technology, Turkey.

[8]. Won, K., Kim, S., Kim, K.-J., \& Park, H. W. (2005). Optimization of Lipase Entrapment in Ca-alginat gel beads. Process Biochemistry $40,2149-2154$.

[9]. Waterborg J.H., 2002. The Lowry Method for Protein Quantitation. Springerlink.

[10]. Yu, J., Zhang, J., Zhao, A., \& Ma, X. (2008). Study of Glucose Ester Synthesis by Immobilized Lipase from Candida sp. Catalysis Communication 9, 1369-1374.

[11]. Hashim, Hasnisa binti dan Jumat Salimon. (2008). Kajian PengoptimumanTindak Balas Hidrolisis Minyak Kacang Soya. The Malaysian Journal of Analytical Science 12, 205-209.

[12]. Fraser, J.E. \& Bickerstaff, G.F. (1997). Entrapment in calcium alginate, in: Bickerstaff, G.F., Methods in Biotechnology (1st ed) ,61-66.

[13]. Tanaka, H., Matsumura, M., \& Veliky, I. A. (1984). Diffusion Characteristics of Substrates in Ca-alginate Gel Beads. Biotechnol Bioeng $26,53-58$.

[14]. Knezevic, Z., Bobic, S., Milutinovic, A., Obradovic, B., Mojovic, L., \& Bugarski, B. (2002). Alginate - Immobilized Lipase by Electrostatic Extrusion for the Purpose of Palm Oil Hydrolysis in Lecithin/Isooctane System. Process Biochemistry 38, 313-318.

[15]. Ozyilmaz, G., \& Gezer, E. (2010). Production of Aroma Esters by Immobilized Candida rugosa and Porcine Pancreatic Lipase into Calcium Alginate Gel. Journal of Molecular Catalysis B: Enzymatic 64 , 140-145.

[16]. Syamsul, M. W. K. (2010). Green synthesis of lauryl palmitate via lipase-catalyzedreaction. Faculty of Science and Technology, Universiti Sains Islam Malaysia(USIM), Malaysia.

[17]. Zaks, A., \& Klibanov, A. M. (1988). The Effect of Water on Enzyme Action in Organic Media. J. Biol. Chem. 263 , 8017-8021.

[18]. Fadıloğlu, S., \& Söylemez, Z. (1997). Kinetics of Lipase-Catalyzed Hydrolysis of Olive Oil. Food Research International 30 , 171175.

[19]. Byun, H. G., et al.(2007). Lipase catalyzed production of monoacylglyserols by theesterification of fish oil fatty acids and with glycerol. Faculty of Science andBiotechnology, Kangnung National University, Korea.

[20]. Patravale, P. B. \&Dandekar, P. P. (2009). Enzymatic Synthetic of Fructose Ester from Mango Kernel Fat. Institute of Chemical Technology, India. 